\title{
Academic Library Futures in a Diversified University System
}

\section{Lorcan Dempsey and Constance Malpas}

\section{Universities (AND Libraries) in Transition}

Following World War II, the higher education sector grew rapidly. The increases in college attendance were dramatic. For example, in 1949, 2.4 million students attended US colleges and universities; by 1969, total enrollment had grown to 8 million students; and by 1994, enrollment had risen to 14.3 million students. And this growth continues. Between 2004 and 2014 , enrollment increased $17 \%$, from 17.3 million to 20.2 million. $^{1}$ As the higher education sector has grown, the number of US academic libraries has increased as well, growing by $6 \%$ from 2002 to 2012, and totaling more than 4000 in $2015 .^{2}$

${ }^{1}$ Thomas D. Snyder, Cristobal de Brey, and Sally A. Dillow, Digest of Education Statistics 2015 (Washington D.C: National Center for Education Statistics, 2016), 460.

${ }^{2}$ Snyder, Brey, and Dillow, Digest of Education Statistics 2015, 881.

L. Dempsey $(\bowtie)$

OCLC, Dublin, OH, USA

e-mail: dempseyl@oclc.org

C. Malpas

OCLC, San Mateo, CA, USA

(C) The Author(s) 2018

N. W. Gleason (ed.), Higher Education in the Era of the Fourth Industrial

Revolution, https://doi.org/10.1007/978-981-13-0194-0_4 
Higher education is now the subject of an intense debate about mission, organization and direction. This is driven by multiple factors, including affordability and inclusion, research evaluation and the associated influence of rankings and increased recognition of the diversification of mission. An important strand in the United States has been the discussion about institutional isomorphism, which has featured centrally in influential recent contributions. ${ }^{3}$ Institutional isomorphism refers to the tendency of institutions in a field to come to resemble each other over time, shaped by coercive (mandated) or normative (professional) influences. In the higher education field, Michael Crow and William Dabars have coined the terms Harvardization or Berkeley envy for a historical trend they observe: universities have aspired to those institutions as common models of excellence. ${ }^{4}$ They, and others, argue that the needs of their constituencies demand a more plural form of education, where different types of institution fit different niches.

And, indeed, it has become increasingly clear that universities are sorting themselves into new patterns of development. For example, Crow's own institution, Arizona State University, is very deliberately charting a course as a new type of mega-university, arguing that it is possible to increase simultaneously both inclusiveness and research excellence. Other patterns are apparent: the residential liberal arts college, for example, which is developing career-oriented professional online offerings (e.g., Indiana Wesleyan University), the regional public university seeking to streamline based on a distinctive career focus (e.g., the University of Texas Rio Grande Valley), the system with shared services (e.g., University of Georgia) and so on. As universities change and grow, so do libraries, and there has also been much discussion of the future of academic libraries. ${ }^{5}$

\footnotetext{
${ }^{3}$ Paul DiMaggio and Walter W. Powell, "The Iron Cage Revisited: Collective Rationality and Institutional Isomorphism in Organizational Fields," American Sociological Review 48, no. 2 (1983): 147-160; Kevin Carey, The End of College: Creating the Future of Learning and the University of Everywhere (New York: Riverhead Books, 2015); Michael M. Crow and William B. Dabars, Designing the New American University (Baltimore: Johns Hopkins University Press, 2015), 118.

${ }^{4}$ Crow and Dabars, Designing the New American University.

${ }^{5}$ For recent examples consider Steven Bell, Lorcan Dempsey, and Barbara Fister, New Roles for the Road Ahead: Essays Commissioned for ACRL's 75th Anniversary (Chicago: Association of College and Research Libraries, 2015); Stephen Pinfield, Andrew M. Cox, and Sophie Rutter, Mapping the Future of Academic Libraries: A Report for SCONUL (London: SCONUL, 2017). https://sconul.ac.uk/sites/default/files/documents/ SCONUL\%20Report\%20Mapping\%20the\%20Future\%20of\%20Academic\%20Libraries.pdf.
} 
Against the university background sketched above, such discussion shares two interesting features. ${ }^{6}$ First, it often proceeds without reference to the universities of which libraries are a part. We contend that the most important long-term influence on the library is the requirement placed on it by changing patterns of research and learning. These changing patterns, in turn, are shaped by the focus of the parent university or college and the directions it is taking. And, as we noted above, a variety of patterns is emerging here. Second, it often presumes some homogeneity of approach or direction, different only in degree among libraries. This presumption of homogeneity encourages a view of academic libraries in which the research library is seen as a terminal point in evolution, rather than as one type among others. However, where universities and colleges seek to differentiate themselves this presumption is increasingly misleading. The models of excellence for libraries supporting, say, an elite comprehensive research university, a liberal arts college devoted to broad-based student learning, or an increasingly career-oriented public institution will be very different from each other.

These factors mean that despite considerable exploration, discussion of library futures can be somewhat partial. We contend that different types of academic libraries will be on different vectors, influenced by the types of universities or colleges they support. In the remainder of this chapter, we will consider the future of academic libraries in the context of a diversifying higher education system. We will proceed as follows. We will consider how the academic library developed in parallel with the growth of the higher education system more broadly. We then will look at some general library trends brought about by the digital shift. We will go on to consider how libraries in different types of higher education institutions will likely develop different emphases to support the specific directions of their host institution. To facilitate this discussion, we propose a simple typology of higher education institutions. This is based on some collaborative work we currently are engaged in to characterize libraries in the context of university strategic directions (in a later stage of this work, we will be looking at developing a more refined view of the library service portfolio supporting different types of university. This is based on field work currently in process). ${ }^{7}$

\footnotetext{
${ }^{6}$ Unless stated otherwise, when we use library in this unqualified sense we mean academic libraries.

${ }^{7}$ The University Futures, Library Futures project is a collaborative initiative of OCLC Research and Ithaka $S+R$, with support from the Andrew W. Mellon Foundation. See "University Futures, Library Futures," OCLC, last updated May 31, 2017, https://www. oclc.org/research/themes/systemwide-library/library-futures.html.
} 
Most of our examples are drawn from the United States, which has an enormously rich and diverse ecosystem of educational provision. Of course, in many other countries there may be a more systemwide approach, guided by public policy and national planning or funding (and this certainly carries over into library provision, where nationally supported shared infrastructures, union catalogs for example, or shared content licensing arrangements, are common). However, we believe that similar trends are observable elsewhere, and that libraries worldwide are on similar trajectories even if they are realized unevenly.

\section{The Collections-Based View of the Library}

The enormous growth in higher education in the post-war period was mirrored by a growth in publication, and of the libraries that managed those publications for universities and colleges. Consider journal publications. ${ }^{8}$ This is the period of De Solla Price's big science, where government funding of big science and technology challenges coincided with the professionalization of research, the emergence of commercial scholarly publishers and "the growing importance of published works as careerdefining tokens of prestige for academics." 9 The academy outsourced reputation management to the publishing system, and at the same time that publishing system was increasingly commercialized. This has led to strenuous discussions about models of open access, funder and national policy attention to the dissemination of research outputs and occasional suggestions that management of the scholarly record be repatriated to the academic community.

On the monograph side, the volume of both consumer and scholarly book publications saw big increases. In 1945, there were a total of 6548 book titles published in the United States. By 1965, the number rose to 28,595 books published. By 1985 , the number rose to 50,070 titles. ${ }^{10} \mathrm{By}$

\footnotetext{
${ }^{8}$ Michael Mabe, "The Growth and Number of Journals," Serials 16, no. 2 (2003): 191-198.

${ }^{9}$ Aileen Fyfe, Kelly Coate, Stephen Curry, Stuart Lawson, Noah Moxham, and Camilla Mørk Røstvik, "Untangling Academic Publishing: A History of the Relationship Between Commercial Interests, Academic Prestige and the Circulation of Research," Zenodo, May 25, 2017, https://zenodo.org/record/546100\#.Wldw-a6nHRY.

${ }^{10}$ Jean Peters, "Book Industry Statistics from the RR Bowker Company," Publishing Research Quarterly 8, no. 3 (1992): 12-23.
} 
the 1970s, these factors had established the traditional collections-based view of the library in the print world. The library was associated strongly with the collection of print materials. A 'good' library was a 'big' library, because it assembled locally a large part of the scholarly and cultural record for prospecting by students and researchers.

Three overlapping central features are worth noting here: identity, value and workflow. The identity of the library was formed by its print incarnation: a central building which makes print collections available. Powerful associations grew up around this: the library at the heart of the university, a physical manifestation of the cumulating scholarly and cultural record, which is created through research and scholarship, shared through teaching and learning, and preserved by the library. These associations are still strong. Indeed, it often is difficult to separate the idea of the library as a 'building' from the idea of the library as a 'service.' Consider media stories about academic libraries: they often will be accompanied by stock images of the Long Room at Trinity College Dublin, or a similar wood-paneled, book-lined library interior.

In parallel, the value of the library was associated strongly with access to the assembled print record, to its organization and to its provision of adjacent study spaces. Until recently, the collections model of libraries has meant that academic libraries have measured their quality or value in terms of how big their collections are-every library trying to be as much like Harvard as possible. In this way, we have had a fairly monolithic model of what constitutes excellence, often focused on collection size, circulation and gate counts, and library expenditures. A university that provided more educational and research materials could offer more comprehensive programs and attract more students. This model of excellence continues to be perpetuated in library rankings and national statistical reporting, which emphasize 'counts' of items (or titles) in the collection, or the size of the library budget relative to other core institutional expenditures.

This centrality is reenforced by workflow. Resources are scarce in a print world, and the library improved student and researcher access by assembling material locally. In a print world, researchers and students built much of their workflow around the collections: you had to work with those materials to get your work done. The library was very much a part of the fabric of research and learning behaviors, because print materials were central to those behaviors. In this way, this model of the library became deeply embedded in behaviors and expectations. 


\section{A Trend Toward Services and Engagement}

However, as the digital shift took hold in the 1970s and later, the print collection gradually became less central to research and learning behaviors (although, of course print collections remain important). At the same time, the deep embeddedness of the library in perceptions, values and workflows has meant that change has not been simple, linear or free of tension. One can point to three summary trends as the digital/network shift emerged. Here, again, it is important to note that it is changes in learning and research behaviors that are the major driver for the library. The library serves the institutions of which it is a part; it does not stand alone.

\section{Reconfiguration of the Information Space by the Network/Digital Environment}

If resources were scarce in the print world, they are certainly now abundant. We have seen an extraordinary growth and diversification of resources in the network environment which support the discovery, creation and use of information resources (see Fig. 4.1).

The network is rich in resources which help create, curate and share information resources. The library collection is potentially an important component, but one component only, of an array of resources and services available to researchers, teachers and learners. This creates an interesting shift for the library. Increasingly, the library facilitates access to external network resources alongside access to its owned or licensed collections. The great growth in use of resource guides is symptomatic of this shift, as are such measures as proxying access to Google Scholar, adding metadata for freely available e-books to the catalog and so on.

\section{Reconfiguration of Research and Learning Work by the Network/ Digital Environment}

While practices vary enormously across individuals, institutions and departments, there have been major changes in how research and learning get done in a network environment. A full discussion of this complex topic is not warranted here, but it is apt to note some issues in relation to the creation and use of information resources.

The first issue relates to the process and product. In the print model, the products of research and learning were fixed publications-articles or 
- arXiv, SSRN, RePEc, PubMed Central (disciplinary repositories that have become important discovery hubs);

- Google Scholar, Google Books, Amazon (ubiquitous discovery and fulfillment hubs);

\section{RePEe}

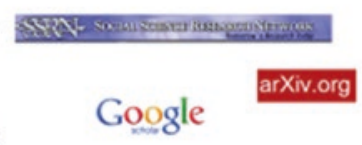

\section{Researchtate zotero}

- Mendeley, ResearchGate (services for social discovery and scholarly reputation management);

- Goodreads, LibraryThing (social description/reading sites);

- Wikipedia, Yahoo Answers, Khan Academy (hubs for open research, reference, and teaching materials).

- FigShare, OpenRefine (data storage and manipulation tools)

- Github (software management)
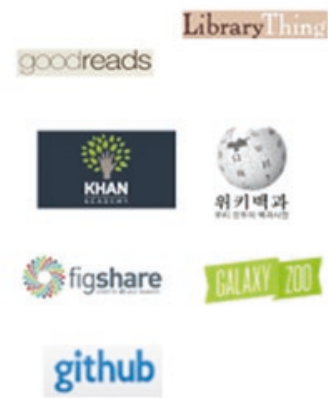

Fig. 4.1 Examples of online information resources

books - produced when the work had been completed. The actual process of research was not visible, nor were intermediate outcomes such as research data, software or methods. Now, in a digital, network environment these intermediate outcomes may be visible and sharable. Moreover, there are arguments, and in some cases mandates, for making these outcomes more readily available in the interests of reproducibility, efficiency, reputation and so on. Similarly, learning materials are potentially of more general interest, and the production of open educational resources is gaining momentum.

In this context, there is a growing role for the library in assisting with the creation and use of institutionally produced materials, or as David Lewis puts it: “... supporting knowledge creation and the curation and preservation of local content." 11 Such local content may include research data, researcher profiles, open educational resources, theses and disserta-

${ }^{11}$ David W. Lewis, Reimagining the Academic Library (Lanham: Rowman \& Littlefield Publishers, 2016), 145. 
tions, workflows, digitized special materials, locally produced video and so on. The curation and disclosure of these resources is a growing interest of libraries and universities, but researchers also have other venues where they share their outputs. These include discipline- or format-specific venues (e.g., Arxiv, the Biologic Specimen, Data Repository and myexperiments.org). General tools may also be used (e.g., GitHub for data and software). The rise of ResearchGate has been interesting in this context. In some countries there is national support for such curation or sharing (e.g., DANS and ANDS in The Netherlands and Australia respectively). And of course, there are now many national or funder imperatives to share these resources.

The second issue is the emergence of research workflow support. This means that workflow support becomes more important as the work of research and learning is enacted in this digital environment. Research and learning behaviors are shaped by, and in turn shape, evolving workflow support services. Workflow, one might say, is the new content. Some examples include

1. curation and sharing of research artifacts: A range of tools and services was discussed in the last section. There are institutional, disciplinary, commercial and publicly supported approaches across a broad range of requirements here, looking at the creation, management, sharing and discovery of resources. These include reference management services, discovery tools, lab notebooks, research networking services, preprint servers, data management services and so on. These are being created by specialist providers, by publishers, by research groups and by many others;

2. research process support: These provide 'prefabricated' workflow support, articulating tools around particular processes. Examples here are laboratory information systems, electronic lab notebooks and scientific workflow systems (e.g., Taverna). And at the same time, researchers assemble their own workflow from many toolscollaborative working and document sharing for instance, or data analysis and visualization approaches.

The emergence of learning and teaching workflow support is a third issue of note. Learning management systems and e-portfolios are now routine, as are various forms of participation environments. Much learning and teaching activity is mediated through a systems environment. 
The blurring of identity, outputs and workflow is also an issue to consider. For many researchers there is increasingly a blurring of content, workflow and network identity as they disclose and share publications and experience in Google Scholar, ResearchGate or other networks as part of ongoing work. At the same time, their institutions similarly are curating and disclosing profiles through VIVO, research information management systems (e.g., Elsevier Pure or Symplectic Elements) and so on. A culture of evaluation and rankings encourages more attention to reputation management at various levels across the academic enterprise.

Another issue to take note of is the use of 'social machines.' We are now very familiar with webscale interaction around network platformsFacebook, eBay and so on. Such 'social machines'12 (Tim Berners-Lee's phrase) are central to many research and learning behaviors. Twitter, GitHub and Wikipedia are obvious examples. However, there are also research-specific resources emerging (e.g., Zooniverse). Many of the resources already mentioned in this section mobilize network communities at scale. In an interesting short article about the future of scholarly communication, David de Roure writes: "Scholarship itself is becoming an in-the-wild experiment in the co-production of social machines."13 Researchers may participate in many communities of interest.

The final issue concerns collaboration. Research is increasingly teambased and cross-institutional. International collaboration is also growing. The percentage of all scientific papers that were internationally coauthored more than doubled in the 20 years after $1990 .{ }^{14}$ This has made it common for researchers to use a variety of collaboration tools and environments to help get their work done.

Again, this creates an important shift for the library. The library can no longer expect learners and researchers to build their workflow around the library, as they did to some extent in a print world. Increasingly, the library has to think about how to make its services and resources available in ways which can be integrated with user behaviors. Putting curated library resources in the learning management system comes to mind. At the same time, the range of services provided by the library is growing, as the library

${ }^{12}$ Tim Berners-Lee, and Mark Fischetti, Weaving the Web: The Original Design and Ultimate Destiny of the World Wide Web by its Inventor (Harper: San Francisco, 1999).

${ }^{13}$ De Roure, "The future of scholarly communications," Insights 27, no. 3 (2014): 237.

${ }^{14}$ Caroline S. Wagner, Han Woo Park, and Loet Leydesdorff, "The continuing growth of global cooperation networks in research: A conundrum for national governments," PLoS One 10, no. 7 (2015): e0131816. 
looks at research and learning workflow support (e.g., research data management), and at a mix of awareness, education and operational support. Libraries are often now providing advice and services around copyright management, citation management, faculty profiles and general reputation management, data management, digital scholarship, creation of open educational resources and so on.

For research libraries especially, this leads to an important distinction, which will cause libraries to think differently about how they organize and direct attention to support research. This is a distinction between outsidein resources and inside-out resources. ${ }^{15}$ The dominant library model of collections has been an outside-in one, where the library is buying or licensing materials from external providers and making them accessible to a local audience. This is an important role and will continue.

In the inside-out model, the university and the library support resources which may be unique to an institution, and the audience is both local and external. The institution's unique intellectual products include archives and special collections, or newly generated research and learning materials (e.g., e-prints, research data, courseware, digital scholarly resources etc.), or such things as expertise or researcher profiles. Often, the goal is to share these materials with potential users outside the institution.

\section{ReCONFIGURATION OF Library COOPERATION By the Network/Digital Environment}

Library cooperation has always been very important. Across the world, libraries collaborate in consortia or within publicly provisioned structures. For example, groups of libraries share the burden of cataloging, have built union catalogs and lend materials to each other through requesting networks. Such collaboration is now extending to the building of shared infrastructure for the management and preservation of digital materials. The network environment makes such collaboration easier to achieve, and shared infrastructure, collections and other capacities will become more common. Eight universities in Hong Kong are collaborating to deploy a single shared library management system, a pattern that is increasingly common. The academic libraries of Ontario have a shared discovery envi-

\footnotetext{
${ }^{15}$ Lorcan Dempsey, "Library Collections in the Life of the User: Two Directions," Liber Quarterly 26, no. 4 (2016): 338-359.
} 
ronment providing access to their collections, as well as other shared infrastructure and services, again a pattern that is increasingly common. Indeed, groups of libraries are looking at how to streamline the whole discovery to delivery logistics apparatus so as to give their users access to the groups' collections as easily as to their own local libraries.

A particularly interesting development here, aligned with our previous comments about collections, is the evolving trend toward moving print collections into shared management arrangements. Given the changes in research and learning behaviors described above, given the pressure on space in many campuses, and given the desire to develop more social space, many libraries are exploring how to manage down their print collections, and in some cases to move them into shared management environments. Several new consortia have been formed around this interest and it has become a central task for others. At the same time, there is considerable interest in building shared facilities for print storage, alongside institutional off-site provision. In fact, in coming years, we can expect to see a large part of the aggregate print resource managed in shared facilities. This has led to discussions of the 'collective collection,' where there is a recognition that there is benefit in shared attention to and management of the aggregate print collection. ${ }^{16}$

What we are seeing, in fact, is a move away from configuring library buildings around collections and toward configuring them around user experiences (e.g., collaborative working, access to specialist materials or expertise and exhibitions). And, indeed, there is something of a renaissance in the construction of new library buildings configured in this way.

\section{Some General Library Trends}

Against this background, we briefly discuss some general library trends. It is interesting to think about what has changed as the library has evolved over the last 25 or so years. The collections-based library still needs to be supported, and the requirements of the services-based or workflows-based library are additive (see Table 4.1).

\footnotetext{
${ }^{16}$ Lorcan Dempsey et al., Understanding the collective collection: towards a system-wide perspective on library print collections (Dublin: OCLC, 2013).
} 
Table 4.1 Changing functions of the library

\begin{tabular}{|c|c|c|}
\hline Term & Collections-based library & Services-based library \\
\hline Library & $\begin{array}{l}\text { Defined by library operation } \\
\text { metrics (collection, reference) }\end{array}$ & $\begin{array}{l}\text { Defined by university needs } \\
\text { (research support, student } \\
\text { success and community } \\
\text { engagement) }\end{array}$ \\
\hline Organization & $\begin{array}{l}\text { Bureaucracy: reproduction of their } \\
\text { system of means is their main } \\
\text { organizational goal }\end{array}$ & $\begin{array}{l}\text { Enterprise: goals, and the change } \\
\text { of goals, shape and endlessly } \\
\text { reshape the structure of means }\end{array}$ \\
\hline Expertise & Subject, process & $\begin{array}{l}\text { Partner in research and learning, } \\
\text { creation etc. }\end{array}$ \\
\hline Systems & Back office & $\begin{array}{l}\text { Workflow, digital scholarship and } \\
\text { shared systems }\end{array}$ \\
\hline Space & Configured around collections & $\begin{array}{l}\text { Configured around user } \\
\text { experiences }\end{array}$ \\
\hline Collections & $\begin{array}{l}\text { Just in case, central, institutional, } \\
\text { consumption }\end{array}$ & $\begin{array}{l}\text { Facilitated (just in time), one } \\
\text { service among others, collective } \\
\text { and creation }\end{array}$ \\
\hline
\end{tabular}

\section{Library}

We have described a shift in emphasis above, from a library built around its collection to one which must think about engagement with research and learning needs in a de-centered network environment. This leads to an important refocusing of how goals are defined. In the print-based library, where purpose and practices were well understood, goals tended to be defined in terms of the library itself, its collections and services. However, the library now increasingly defines itself in terms of university needs in a changing environment-how to make research more productive, how to contribute to student success and retention, how to improve the engagement between the university and its community and so on.

\section{Organization}

Manuel Castells distinguishes between bureaucracies and enterprises. ${ }^{17}$ The stable and well-understood goals of the print-based library favored a focus on managing and improving the means toward those goals-building the collection, providing reference service, creating efficiencies in

${ }^{17}$ Castells, The rise of the network society (Malden: Wiley-Blackwell, 2012). 
technical processing and so on. This was the focus of professional practice and education. Much of this work is inherently bureaucratic. However, as goals shift in a changing environment, so does the need to think about how to marshal the means to meet them. This may require reorganization, new staff skills, changes in existing priorities, and reallocation of staff and resources. This requires a shift in culture from bureaucracy to enterprise, and the creation of a more adaptive organization that reviews and reshapes what it does in light of changing requirements.

\section{Expertise}

This in turn leads to a diversification of skills. As the library partners in research and learning, a broad range of competencies potentially come into play-pedagogy, copyright, marketing, exhibitions, digital asset management, data science and so on.

\section{Systems}

The focus of library automation has been on managing collections, and a sophisticated apparatus for managing print, licensed and digital collections has emerged. This is largely a back-office operation. In the services-based library, there is greater need for support for research and learning workflows, for building systems around communities and people as well as around collections. The library provides advice and consultancy about a range of other systems and services.

\section{Space}

With regard to space, buildings are historically configured around collections and their use. Nevertheless, libraries are increasingly being configured around user experiences. This means that libraries are reflecting on what collections should be maintained locally, taking a more specialized view of this.

\section{Collections}

We have spoken about the changing nature of collections throughout this chapter. To some extent, the familiar continuity of the view of the library shelves, or the library search box, obscures the multiple ways in which 
library support around the creation, management and discoverability of content has changed. ${ }^{18}$

Some of the changes we have noted regarding collections are:

1. facilitated collections: A shift from just in case collecting to more of a just in time or facilitated approach. This includes a move to patrondriven acquisition and considerable effort devoted to providing guided access to materials outside the library (e.g., resource guides, etc.);

2. collections as a service: The collection anchors important services, but increasingly other services are also important. Many library services are not collection-based;

3. collective collections: There is a move to collective management of print collections. At the same time, there is a recognition that digital collections need to be aggregated for discovery purposes for maximum impact.

From consumption to creation: The library provides support for creation of resources in a digital environment, as well as their consumption. This may be support for digital scholarship, video production, creation of learning materials and so on.

\section{The Services-Based Library}

As the transition we have spoken about continues, the library story changes. One of the current challenges for the library is articulating that new story. We spoke about identity, value and workflow above. Libraries are forging a new engagement-based identity which is not anchored in a building or a collection, but rather as a partner in the creative process of learning and research. There is also an active value discussion, as libraries explore how to define value not in terms of inputs (e.g., the size of collection and gate counts) but in terms of impact. Libraries are building services around the network-based workflows of their users, and those workflows encompass many information resources alongside those acquired by the library. This means that the presence of the library becomes more diffused. Does the library user recognize, for example, that a journal article is actually accessible to them because of a library subscription?

${ }^{18}$ Lorcan Dempsey, Constance Malpas, and Brian F. Lavoie, "Collection directions: the evolution of library collections and collecting," portal: Libraries and the Academy 14, no. 3 (2014): 393-423; Dempsey, "Library Collections in the Life of the User: Two Directions." 
Against this background, it becomes important for the new library story to be compellingly told. And important that library staff be visible in campus discussions, committees, research projects and classrooms. For convenience of designation, we refer to the evolving library as the servicesbased library, acknowledging that this is a somewhat general characterization. However, for our purposes here it is convenient as a way of contrasting with the collections-based library of the past. ${ }^{19}$ As the library becomes more deeply engaged in the research and learning behaviors of its community, it is not surprising that we see greater diversification, as the communities that libraries serve are different. We now turn to a discussion of how those university and college communities are in fact diversifying, and in turn refocusing the library service profiles within their institutions.

\section{Institutional Typology: Capturing Diversification}

Analyses of the higher education sector in the United States typically rely on one or both of the institutional taxonomies developed by the US Department of Education's National Center for Education Statistics (NCES) and the Carnegie Foundation. These provide a sector-based view of the institutional landscape, categorizing universities by control (public, private) and levels of degree conferred. Though widely used, these taxonomies fall short of representing the diversity and increasing stratification of post-secondary education. ${ }^{20}$ Some years ago, a study by the Chronicle of Higher Education proposed a more dynamic framework based on university business models. ${ }^{21}$ This had the advantage of seeing universities as evolving, rather than as static members of a class. However, it was a basic model and has not been updated since 2009 . Nor has it been widely picked up or operationalized. Simply, it proposed two models which it saw as thriving (elite and convenience), and suggested that those institutions in the 'middle', who tried to be all things to all people, would have to specialize more in order to succeed.

\footnotetext{
${ }^{19}$ For some discussion of a turn to services, see: Scott Walter, "'Distinctive Signifiers of Excellence': Library services and the future of the academic library," College \& Research Libraries 72, no. 1 (2011): 6-8.

${ }^{20}$ Brian Prescott, "Thinking Anew About Institutional Taxonomies" (paper, Mapping Broad-Access Higher Education Convening at Stanford University, Stanford, CA, November 22, 2011).

${ }^{21}$ Martin Van der Werf and Grant Sabatier, The College of 2020: Students (Washington, DC: Chronicle Research Services, 2009).
} 
As part of our ongoing research project with colleagues at Ithaka $S+R$, OCLC Research has developed a working model to help explore the diversification of university activity in the United States. Our approach is data driven, and relies on national survey data compiled by the US Department of Education in the Integrated Postsecondary Educational Data System (IPEDS). ${ }^{22}$ Using data from the 2015 survey cycle, we have computed institutional profiles for 1500 colleges and universities, focused on two primary dimensions. ${ }^{23}$ The first dimension characterizes the balance of institutional attention devoted to research (specifically, doctoral-level scholarship), liberal education (arts-and-sciences-focused baccalaureate education) and career preparation (professional degree and non-degree certificate programs). The second dimension characterizes the mode of educational provision, on a continuum between traditional residential programs designed for full-time, on-campus students and more flexible offerings designed for 'new traditional' students, including part-time, adult and distance learners. Here, we focus on our analysis of the first dimension, exploring directions in educational activity.

Applying this working model to a large segment of the US higher education sector, as we have done, makes it possible to distinguish important differences in institutional direction. A key benefit of our multi-dimensional analysis is that it readily enables visualization of institutional types based on the relative emphasis of educational activity and mode of provision. Figure 4.2 shows an application of this kind of visualization, comparing average values for two different cohorts with distinctively different institutional profiles: members of the Oberlin Group association of liberal arts colleges and members of the Association of American Universities (AAU), which gather leading research universities in the United States. While differences between liberal arts colleges and elite, research-intensive universities are widely recognized and could be easily intuited, our model provides a means of measuring and comparing the strength of institutional types across different populations. It is possible to explore both the significance of institutional isomorphism in the US higher education landscape (the

\footnotetext{
22 "Data Submission Requirement," National Center for Education Statistics, accessed December 28, 2017, https://surveys.nces.ed.gov/ipeds/.

${ }^{23}$ Our current study is limited to non-profit (private and public) institutions, excluding community colleges. Our project population of 1500 institutions represents about a third of the US post-secondary population, representing colleges and universities that meet our scoping criteria, for which sufficient 2015 IPEDS survey data were available for analysis.
} 
Fig. 4.2 Comparison of institutional profiles between the AAU and Oberlin Group
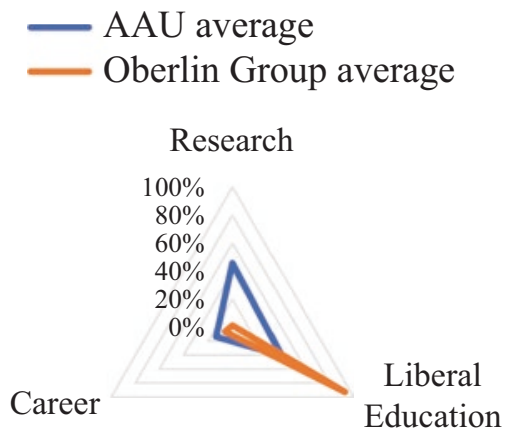

strong conformance to type exhibited within cohorts) and the diversity of institutional identity within those 'strongly typed' patterns.

A further value of our model is that it supports comparative analysis of institutional directions along multiple lines of business in which colleges and universities typically engage. ${ }^{24}$ As post-secondary institutions adapt to evolving market needs (adding new professional master's programs to an established undergraduate education program, for example), academic libraries will need to tune and refine their services to support diversifying institutional needs. Even within institutional cohorts with a strong shared identity, such as the Oberlin Group, our model reveals significant diversity of institutional purpose. As Fig. 4.3 shows, there is substantial variance around the mean (average) values for the group, with some Oberlin Group members exhibiting significant institutional activity around career-related programs, while others exhibit a narrower focus on the interdisciplinary arts and sciences baccalaureate that is commonly viewed as the hallmark of liberal arts college education.

It is important to consider the implications of this diversity for models of academic library service, and benchmarks for library evaluation. While the familiar Carnegie Classification of postsecondary institutions has undergone multiple revisions in recent years, it is still common for US

\footnotetext{
${ }^{24} \mathrm{We}$ do not pretend that the three lines of business (research, liberal education, career preparation) addressed in our model provide a comprehensive view of university activity. For instance, community engagement is a strategic priority for many colleges and universities, but is not represented in our framework. Because our model is derived from statistical indicators captured in the national IPEDS survey, we are limited to analysis of activities for which statistical variables have been defined or can be readily derived.
} 
Fig. 4.3 Variance in institutional purpose within the Oberlin Group

\section{Oberlin Group $(\mathrm{n}=83)$}

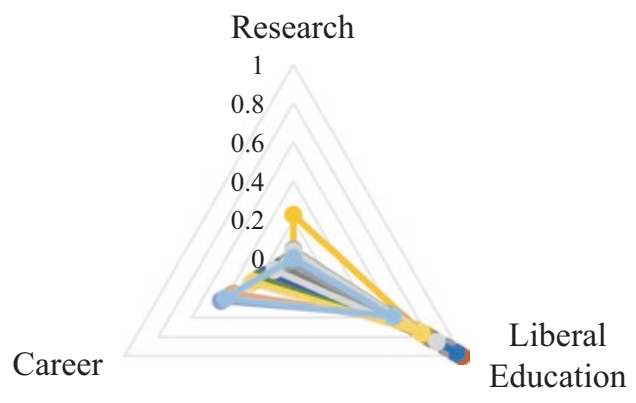

libraries to rely on service benchmarks based on average values for 'basic' Carnegie classes such as Masters/Medium or Doctoral/Moderate Research Activity.

Yet, the library needs of a research university—of any size or intensity of research activity - with a significant commitment (and reputational stake) in liberal education of undergraduates, will differ from those of a research university focused more strongly on graduate education, or indeed a research university that is diversifying its offer to include more professional masters programs. Similarly, a liberal arts college with a burgeoning online master's or adult degree-completion program will have different library needs than a liberal arts college that has retained a focus on residential learning tailored to the needs of 'traditional' full-time students. Ongoing demographic change in the undergraduate enrollment pipeline is likely to accelerate the diversification of post-secondary educational offerings, with knock-on effects on the organization and provision of academic library service. Similarly, a shift from a residential focus to more convenience-based offerings potentially calls for a different approach to library services, a more focused tailoring around course requirements or greater visibility in learning and teaching workflows.

\section{ACADEMIC Libraries in A DiversifIED Higher Education Sector}

While research on higher education has clearly identified a need for increased attention to increasing differentiation in the post-secondary landscape, we have already noted how discussions about the future of aca- 
demic libraries still generally rely on broad characterizations of the higher education enterprise. Assessment still tends to emphasize the means of the academic library, rather than the ends it serves. Consequently, there is not much attention to efficiency as a measure of success, nor is there attention to the different needs and expectations of different kinds of parent institutions. Of course, this is recognized and it is one reason that we have seen increased discussion of library value in recent years.

For example, recent work at ACRL has focused on library support for student success and increased library engagement in support of research, teaching and learning. ${ }^{25}$ As accreditation standards emphasize the importance of aligning library collections and services with local institutional priorities, it is likely that there will need to be greater attention to prevailing patterns of need (or models of service excellence) in different institution types. Our effort to delineate different institution types based on the relative distribution of activity in research, liberal education and career preparation is intended to support a broad discussion of future library directions in institutions that will look less similar in the future than they do today.

It is clear that libraries in different types of universities already make investments in different types of services. However, it is likely that increased diversification of higher education institutions will drive increased diversification of library service models. For example, a research library will have strong incentives to provide support for emerging forms of digital scholarship, and to provide curatorial services for a broad range of research outputs (as per our discussion of the inside-out library above). ${ }^{26} \mathrm{~A}$ library in a teaching-focused institution may invest more in services supporting

\footnotetext{
${ }^{25}$ Association of College and Research Libraries, Academic Library Impact on Student Learning and Success: Findings from Assessment in Action Team Projects (Chicago: Association of College and Research Libraries, 2017).

${ }^{26}$ Recent work by Carol Tenopir and colleagues has established a statistically significant relationship between the size of an academic institution and the robustness of the library research data management $(\mathrm{RDM})$ service offering. Institutions with a full-time student enrollment greater than 5000 were observed to offer a broader range of consultative RDM services than smaller institutions. See Carol Tenopir, Ben Birch, and Suzie Allard, Academic Libraries and Research Data Services: Current Practices and Plans for the Future: An ACRL White Paper (Chicago: Association of College and Research Libraries, 2012). While we do not regard institution size, in isolation, as a reliable indicator of distinctive university type (for the purposes of our project), the positive correlation between institution size and RDM service portfolio is noteworthy.
} 
student success. ${ }^{27}$ Some libraries will assume responsibility for the print scholarly record; others will gradually divest. ${ }^{28}$ Likewise, the sourcing of core services will vary: some will be internalized and promoted as institutional differentiators; others may be externalized to third parties. ${ }^{29}$ And, as noted above, universities that are supporting an increasingly diverse range of educational offers may require multiple bundles of library service, and source those services through a variety of arrangements.

Returning to the three areas of institutional activity captured in our working model, it is useful to consider the alignment of some of the library services we have spoken about with university directions. Researchintensive universities increasingly expect libraries to provide support for emerging disciplinary workflows (electronic laboratory notebooks, computational approaches to textual analysis) alongside support for traditional, paper-based workflows. Research libraries may also have a role in supporting the university research enterprise through implementation and support of research information management systems (or CRISes) to automate faculty performance review, promotion and tenure. Comprehensive universities that combine high levels of research with large-scale undergradu-

${ }^{27}$ For example, DePaul University library has integrated library-based support services into the local implementation of Starfish, a commercially licensed learning analytics and student retention system. See: Scott Walter, "Library Research Services Now Available in BlueStar," October 17, 2016, https://news.library.depaul.press/faculty/2016/10/17/libraryresearch-services-now-available-in-bluestar/. A growing number of college and university libraries now offer specialized student success services designed to increase student engagement and achievement. This trend is explored in a 2015 blog post by Steven Bell in Bell, “AKA 'The Student Success Center," Library Journal, July 8, 2015, http://lj.libraryjournal.com/2015/07/opinion/steven-bell/aka-the-student-success-center-fromthe-bell-tower\#_.

${ }^{28}$ Until very recently, the only libraries registering explicit retention commitments for print collections in the WorldCat union catalog were large university research libraries. As more shared print partnerships emerge, with broader representation of the academic library community, we expect to see a mix of institution types participating in distributed retention programs. For example, the Eastern Academic Storage Trust initiative includes many liberal arts college and mid-size university libraries as retention partners. See "Members," Eastern Academic Scholars' Trust, accessed January 11, 2018, https://eastlibraries.org/members. As part of the proposed project, we plan to investigate how different library types perceive their institutional responsibility to preservation of the print record.

${ }^{29}$ We explore institutional choices about internalizing or externalizing research data management capacity in The Realities of Research Data Management, a four-part series of reports from OCLC Research. See: "The Realities of Research Data Management," OCLC, accessed December 28, 2017, https://www.oclc.org/research/publications/2017/oclcresearchresearch-data-management.html. 
ate education may look to the library for support with data-driven analytics of teaching and learning outcomes. Institutions that specialize in undergraduate liberal education will have less need for library support for research workflows or related infrastructure, but may expect the library to take a leadership role in the selection and implementation of e-portfolio systems for managing and tracking student learning outcomes, or supporting faculty use of open educational resources. Colleges and universities with a career-directed outlook will typically require library support for digital information literacy, access to core collections and workflow and other tools to support student success (assignment calendars and other time-management tools, academic coaching services).

Based on the patterns noted here, it is possible to abstract a general picture of emerging service models in different academic settings that is largely borne out by empirical observation. Academic libraries in researchintensive institutions are increasingly preoccupied with support for digital research workflows and are making substantial investments in appropriate software and services, alongside continued investment in traditional, collection-centric activities. College and university libraries in institutions with less graduate-level research have less robust research data management infrastructure, for example, but position themselves more explicitly as partners in instructional design and collaborative learning. Libraries in institutions that are pivoting toward more career-directed programming are creating space for career counseling services within the library, aligning library services with 'real world' work experience and promoting the library as a partner in preparing for life after college. These service patterns reflect strategic choices that promote increased alignment of library activity with broader institutional interests and over time will result in a more diversified academic library landscape.

Nevertheless, services-oriented libraries take directions in different institutional settings. Some emerging service areas are shared, but most are not (see Table 4.2). This is a reflection of the diverging institutional identities and interests of colleges and universities seeking to differentiate their educational offer to compete for enrollment, revenue (tuition and research funding) and reputation. In a services-oriented environment, the library's identity and value are associated with the specialized research, teaching and learning workflows it supports. And with more institutions striving to identify a distinctive niche in which to succeed, we can anticipate that academic library models will look more different than alike. There will be multiple models of library excellence, but also limited toler- 
Table 4.2 Differing directions of a services-oriented library

\begin{tabular}{|c|c|c|c|}
\hline & Research & Liberal education & Career \\
\hline $\begin{array}{l}\text { Emerging library } \\
\text { services }\end{array}$ & $\begin{array}{l}\text { Research data } \\
\text { management (data } \\
\text { repositories, data } \\
\text { management plans, e-lab } \\
\text { notebooks), research } \\
\text { information } \\
\text { management (tracking } \\
\text { university research } \\
\text { outputs), and data } \\
\text { analysis and visualization }\end{array}$ & $\begin{array}{l}\text { E-portfolios, open } \\
\text { educational resources, } \\
\text { library support for } \\
\text { instructional design, } \\
\text { integration of library } \\
\text { content in institutional } \\
\text { LMS, special collections } \\
\text { integrated within } \\
\text { undergraduate research } \\
\text { programs }\end{array}$ & $\begin{array}{l}\text { E-portfolio and } \\
\text { fab labs }\end{array}$ \\
\hline Staffing & $\begin{array}{l}\text { Specialized research } \\
\text { support librarians } \\
\text { (including PhDs) }\end{array}$ & Student success librarian & $\begin{array}{l}\text { First-year } \\
\text { experience } \\
\text { librarian }\end{array}$ \\
\hline $\begin{array}{l}\text { Shared } \\
\text { infrastructure }\end{array}$ & $\begin{array}{l}\text { Shared print repositories, } \\
\text { shared research data } \\
\text { repositories and } \\
\text { consortial borrowing } \\
\text { networks }\end{array}$ & $\begin{array}{l}\text { Shared print repositories, } \\
\text { shared OER repositories } \\
\text { and consortial } \\
\text { borrowing networks }\end{array}$ & $\begin{array}{l}\text { 'Library in a } \\
\text { box' licensed } \\
\text { collections, } \\
\text { shared, } \\
\text { multi-tenant } \\
\text { ILS }\end{array}$ \\
\hline
\end{tabular}

ance for libraries that preserve or emulate a service model that is not a good fit with current institutional needs.

\section{Conclusion}

We have discussed how the academic library story has changed. Libraries are transitioning from a collections-based model to a more broadly services-based model. This is inevitable, as students, teachers and researchers inhabit a rich network information environment, and as their work is increasingly enacted in digital, network workflows. The library's role is no longer to assemble a large local collection. It is to support their users' creative activity in more diffuse ways - as a partner and an advocate. Of course, collections remain important as a component of a broader service array and the library role in licensing electronic materials is still central. This has been a gradual shift, and library identity, value and workflows are being refashioned.

We have also discussed how university emphases can be characterized in relation to three poles: research, liberal education and career prepared- 
ness. At the same time, universities have different and evolving balances between residential and convenience orientations. While universities are complex organizations and are variably inserted in national policy or planning contexts, this model does provide a way of thinking about directional patterns. Importantly for our purposes it also provides a context for thinking about library directions.

In the collections-based environment (arguably superseded, but still influential in identity, value and workflow discussions), libraries shared many characteristics. As we move toward a services-based library which values strong engagement with its home institution, it is natural for libraries to diverge more, in line with the character of those home institutions. Of course, this is within a broadly familiar envelope of services, but emphasis and priority shift. This means that models of excellence also shift, as value is not assessed in terms of collection size or gate count, but in terms of fit to the goals of the home university. This is a great moment for university libraries - as they redefine what it means to support the research, teaching, learning, and engagement goals of their universities and colleges.

\section{BIBLIOGRAPHY}

Association of College and Research Libraries. Academic Library Impact on Student Learning and Success: Findings from Assessment in Action Team Projects. Chicago: Association of College and Research Libraries, 2017.

Bell, Steven. “AKA 'The Student Success Center.” Library Journal, July 8, 2015. http://lj.libraryjournal.com/2015/07/opinion/steven-bell/aka-the-studentsuccess-center-from-the-bell-tower\#_.

Bell, Steven, Lorcan Dempsey, and Barbara Fister. New Roles for the Road Ahead: Essays Commissioned for ACRL's 75th Anniversary. Chicago: Association of College and Research Libraries, 2015.

Berners-Lee, Tim, and Mark Fischetti. Weaving the Web: The Original Design and Ultimate Destiny of the World Wide Web by its Inventor. Harper: San Francisco, 1999.

Castells, Manuel. The rise of the network society. Malden: Wiley-Blackwell, 2012.

Carey, Kevin. The End of College: Creating the Future of Learning and the University of Everywhere. New York: Riverhead Books, 2015.

Crow, Michael M., and William B. Dabars. Designing the New American University. Baltimore: Johns Hopkins University Press, 2015.

Dempsey, Lorcan. "Library Collections in the Life of the User: Two Directions." Liber Quarterly 26, no. 4 (2016): 338-359. 
Dempsey, Lorcan, Brian F. Lavoie, Constance Malpas, Lynn Silipigni Connaway, Roger C. Schonfeld, JD Shipengrover, and Günter Waibel. Understanding the collective collection: towards a system-wide perspective on library print collections. Dublin: OCLC Research, 2013.

Dempsey, Lorcan, Constance Malpas, and Brian F. Lavoie. "Collection directions: the evolution of library collections and collecting." portal: Libraries and the Academy 14, no. 3 (2014): 393-423.

De Roure, David. "The future of scholarly communications." Insights 27 , no. 3 (2014): 233-238.

DiMaggio, Paul, and Walter W. Powell. “The Iron Cage Revisited: Collective Rationality and Institutional Isomorphism in Organizational Fields." American Sociological Review 48, no. 2 (1983): 147-160.

Eastern Academic Scholars' Trust. “Members.” Accessed January 11, 2018. https://eastlibraries.org/members.

Fyfe, Aileen, Kelly Coate, Stephen Curry, Stuart Lawson, Noah Moxham, and Camilla Mørk Røstvik. "Untangling Academic Publishing: A History of the Relationship Between Commercial Interests, Academic Prestige and the Circulation of Research." Zenodo, May 25, 2017. https://zenodo.org/ record/546100\#.Wldw-a6nHRY.

Lewis, David W. Reimagining the Academic Library. Lanham: Rowman \& Littlefield Publishers, 2016.

Mabe, Michael. "The Growth and Number of Journals." Serials 16, no. 2 (2003): 191-198.

National Center for Education Statistics. "Data Submission Requirement." Accessed December 28, 2017. https://surveys.nces.ed.gov/ipeds/.

OCLC. "University Futures, Library Futures." Last updated May 31, 2017. https://www.oclc.org/research/themes/systemwide-library/library-futures. html.

- "The Realities of Research Data Management." Accessed December 28, 2017. https://www.oclc.org/research/publications/2017/oclcresearchresearch-data-management.html.

Peters, Jean. "Book Industry Statistics from the RR Bowker Company." Publishing Research Quarterly 8, no. 3 (1992): 12-23.

Pinfield, Stephen, Andrew M. Cox, and Sophie Rutter. Mapping the Future of Academic Libraries: A Report for SCONUL. London: SCONUL, 2017. https://sconul.ac.uk/sites/default/files/documents /SCONUL\% 20Report\%20Mapping\%20the\%20Future\%20of\%20Academic\%20Libraries.pdf.

Prescott, Brian. “Thinking Anew About Institutional Taxonomies." Paper presented at the Mapping Broad-Access Higher Education Convening at Stanford University, Stanford, CA, November 22, 2011. 
Snyder, Thomas D., Cristobal de Brey, and Sally A. Dillow. Digest of Education Statistics 2015. Washington, D.C.: National Center for Education Statistics, 2016.

Tenopir, Carol, Ben Birch, and Suzie Allard. Academic Libraries and Research Data Services: Current Practices and Plans for the Future: An ACRL White Paper. Chicago: Association of College and Research Libraries, 2012.

Van der Werf, Martin, and Grant Sabatier. The College of 2020: Students. Washington, D.C.: Chronicle Research Services, 2009.

Wagner, Caroline S., Han Woo Park, and Loet Leydesdorff. "The continuing growth of global cooperation networks in research: A conundrum for national governments." PLoS One 10, no. 7 (2015): e0131816.

Walter, Scott. "'Distinctive Signifiers of Excellence': Library services and the future of the academic library." College \& Research Libraries 72, no. I (2011): 6-8.

. "Library Research Services Now Available in BlueStar." October 17, 2016. https://news.library.depaul.press/faculty/2016/10/17/library-researchservices-now-available-in-bluestar/.

Open Access This chapter is licensed under the terms of the Creative Commons Attribution 4.0 International License (http://creativecommons.org/licenses/ by $/ 4.0 /)$, which permits use, sharing, adaptation, distribution and reproduction in any medium or format, as long as you give appropriate credit to the original author(s) and the source, provide a link to the Creative Commons license and indicate if changes were made.

The images or other third party material in this chapter are included in the chapter's Creative Commons license, unless indicated otherwise in a credit line to the material. If material is not included in the chapter's Creative Commons license and your intended use is not permitted by statutory regulation or exceeds the permitted use, you will need to obtain permission directly from the copyright holder.

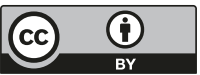

